\title{
The effects of breads containing similar amounts of phytate but different amounts of wheat bran on calcium, zinc and iron balance in man
}

\author{
BY H. ANDERSSON ${ }^{1}$, B. NÄVERT ${ }^{1}$, S. A. BINGHAM ${ }^{2}$, H. N. ENGLYST ${ }^{1}$ \\ AND J. H. CUMMINGS ${ }^{2}$ \\ ${ }^{1}$ Department of Clinical Nutrition, Sahlgren's Hospital, Gothenburg, Sweden and \\ ${ }^{2}$ Dunn Clinical Nutrition Unit, Old Addenbrooke's Hospital, Trumpington Street, \\ Cambridge CB2 $1 Q E$
}

(Received 7 January 1983 - Accepted 17 May 1983)

\begin{abstract}
1. The capacity of wheat bran to impair mineral absorption independent of its phytate content was studied by metabolic balance studies in man.

2. Three breads were prepared, equivalent to white, brown and wholemeal, by adding bran in different quantities to white flour. Calcium, iron, zinc and sodium phytate were added to the loaves to make the amounts equal in all breads.

3. Six healthy volunteers were studied for three consecutive 24-d-periods during which they ate a controlled diet, typical of that normally consumed in the UK but with $200 \mathrm{~g}$ bread/d. Only the type of bread changed between each dietary period.

4. The phytate contents ( $\mathrm{mmol}$ ) of $200 \mathrm{~g}$ of each of the breads after baking were: white $2 \cdot 3$, brown $2 \cdot 1$ and wholemeal $2 \cdot 2$; non-starch polysaccharide contents $(\mathrm{g})$ were: white $3 \cdot 3$, brown 10.9 and wholemeal $18 \cdot 7$

5. The increased amount of bran in the breads increased stool output in the expected way but no change was seen in $\mathrm{Ca}, \mathrm{Zn}$ and $\mathrm{Fe}$ balance. Blood levels of these minerals remained unchanged.

6. It is concluded that wheat bran and, in particular, the cell-wall polysaccharides of bran, are untikely to exert a significant effect on mineral absorption in man, in amounts customarily eaten, independently of the effect of phytate present in the bran.
\end{abstract}

Wheat bran is a mixture of many substances, two of which, phytic acid and non-starch polysaccharides, have been implicated in the diminished efficiency of absorption of minerals, especially divalent cations, seen in subjects eating brown or whole-grain products.

Diets rich in dietary fibre, especially wheat bran, are now used in medical practice to treat bowel disorders (Royal College of Physicians, 1980) and in addition are recommended as part of the National dietary goals of a number of countries. However, the absorption of zinc decreases if the diet contains wholemeal bread (Sandström et al. 1980) or $16 \mathrm{~g}$ of wheat bran daily (Sandberg et al. 1982) but, in another study, $26 \mathrm{~g}$ of wheat bran or maize bran was not enough to give significant results (Sandstead et al. 1978). Vegetables (Kelsay et al. 1979 ) and psyllium (Drews et al. 1979; Kies et al. 1979) have also been shown to reduce $\mathrm{Zn}$ availability. Clinical studies also indicate that negative mineral balances may occur with fibre-rich diets especially in the elderly (Persson et al. 1976; Andersson et al. 1979).

In order to determine whether cell wall material from cereals affects mineral balance separately from phytic acid we have measured $\mathrm{Ca}, \mathrm{Mg}, \mathrm{Fe}$ and $\mathrm{Zn}$ balances in healthy subjects whilst consuming three breads containing different amounts of bran. Sodium phytate was added to the breads to equalize the amounts and enable the effect of the other components together to be tested. 


\section{EXPERIMENT A L}

Subjects and methods

Six healthy volunteers aged 25-55 years (five men and one woman) were each studied for three consecutive 24-d-periods. During the study they lived in the metabolic suite of the Dunn Clinical Nutrition Centre but were allowed to go out and continue with their normal work. All food was provided by the diet kitchen and no alcohol or extra food was permitted.

The volunteers were weighed weekly and blood samples were obtained for $\mathrm{Ca}, \mathrm{Fe}, \mathrm{Mg}$ and $\mathrm{Zn}$ at the start and end of each 24 -d-period.

\section{Diet}

Before the study each subject undertook to weigh and record all food and drink eaten for $7 \mathrm{~d}$ in order to determine quantitatively their normal energy and nutrient intakes (Bingham et al. 1981).

For the whole of the study, three 1-d-menus of similar composition were prepared and fed in rotation. The menu was the same each day except for the main meals. Energy intake was adjusted at the start of the study in order to keep the weights of the subjects constant, by altering the intake of sugar, jam, butter, cream, potatoes and chicken or turkey. All food was prepared in the 'metabolic' kitchen and was bought in bulk when available at the beginning of the study period. Only deionized water was allowed. The diet was the same throughout the study except for the type of bread. During each 24-d-period either white, brown or wholemeal bread was fed in random order.

The over-all daily nutrient composition of the basal diet, calculated from McCance and Widdowson's food tables (Paul \& Southgate, 1978) was: energy 8.12 MJ, fat 74 g, protein $76 \mathrm{~g}$, carbohydrate $256 \mathrm{~g}$, fibre $18.5 \mathrm{~g}$. In order to keep Ca intake as close as possible to the subjects' normal intakes enough calcium carbonate was added to each person's soup each day to bring their intakes up to the level measured during their $7 \mathrm{~d}$ food records.

Table 1 shows intakes of energy, $\mathrm{Ca}, \mathrm{Zn}, \mathrm{Fe}$ and $\mathrm{Mg}$ in each individual subject. Eight complete collections of each of the three menus were made. These diets were homogenized, freeze-dried and portions taken for analysis.

\section{Bread}

All the bread was baked before the study at Dalgety-Spillers Research Centre in Cambridge. The composition was similar except that bran was substituted for white flour in differing amounts to make the brown and wholemeal loaves and additional zinc sulphate, ferrous sulphate and $\mathrm{CaCO}_{3}$ added to bring the amounts of $\mathrm{Zn}, \mathrm{Fe}$ and $\mathrm{Ca}$ up to an equal level in all three loaves. The different breads $(200 \mathrm{~g})$ were fed daily at breakfast.

\section{Phytate}

To keep the phytate content constant during the study, sodium phytate (inositol hexaphosphoric acid as sodium salt; BDH Ltd, Poole, Dorset) was added to the dough of the white and brown breads in amounts sufficient to make these breads equal to the phytate content of the wholemeal bread; $2.5 \mathrm{mmol}$ were added per $200 \mathrm{~g}$ white bread and $1.6 \mathrm{mmol}$ per $200 \mathrm{~g}$ brown bread.

\section{Balance markers}

Throughout the study each subject took 30 radiopaque pellets (ten per meal) as a non-absorbable marker. Two different shapes of marker were used, each type being given for $24 \mathrm{~d}$ and then changed in order to distinguish the different dietary periods. Marker recovery in the stools was measured by X-ray and the values used both for calculation of 
Table 1. Total daily intake of energy, calcium, zinc, iron and magnesium

\begin{tabular}{|c|c|c|c|c|c|c|c|}
\hline \multirow[b]{2}{*}{$\begin{array}{c}\text { Subject } \\
\text { no. }\end{array}$} & \multirow[b]{2}{*}{$\begin{array}{c}\text { Energy } \\
(\mathrm{MJ})\end{array}$} & \multirow[b]{2}{*}{$\underset{(\mathrm{mmol})}{\mathrm{Ca}^{*}}$} & \multirow[b]{2}{*}{$\underset{(\mu \mathrm{mol})}{\mathrm{Zn} \dagger}$} & \multirow[b]{2}{*}{$\underset{(\mu \mathrm{mol})}{\mathrm{Fe}}$} & \multicolumn{3}{|c|}{$\mathrm{Mg}(\mathrm{mmol}) \dagger$} \\
\hline & & & & & $\begin{array}{l}\text { White } \\
\text { bread }\end{array}$ & $\begin{array}{l}\text { Brown } \\
\text { bread }\end{array}$ & $\begin{array}{c}\text { Wholemeal } \\
\text { bread }\end{array}$ \\
\hline 1 & $8 \cdot 12$ & 33.5 & 163 & 229 & $8 \cdot 3$ & 11.4 & $15 \cdot 3$ \\
\hline 2 & 11.08 & 32.5 & 168 & 255 & $9 \cdot 3$ & 12.4 & $16 \cdot 3$ \\
\hline 3 & 11.08 & $34 \cdot 4$ & 168 & 255 & $9 \cdot 3$ & $12 \cdot 4$ & $16 \cdot 3$ \\
\hline 4 & 12.04 & $33 \cdot 2$ & 172 & 262 & 9.8 & $12 \cdot 9$ & 16.8 \\
\hline 5 & 12.04 & 34.6 & 172 & 262 & 9.8 & $12 \cdot 9$ & 16.8 \\
\hline 6 & 15.00 & $40 \cdot 6$ & 179 & 282 & 10.8 & 13.9 & 17.8 \\
\hline
\end{tabular}

* Calculated from McCance and Widdowson's The Composition of Foods (Paul \& Southgate, 1978).

$\uparrow$ Analysed values.

the mean transit time (MTT; Cummings et al. 1976) and as a balance marker for the correction of faecal weight and mineral output as previously reported (Branch \& Cummings, 1978).

\section{Faecal and urine collections}

Faeces were collected daily for the whole of the study, each stool being passed into a plastic bag fixed over a toilet. The bag was then sealed, labelled and frozen. Every stool was weighed, X-rayed, pooled in 6-d-portions then freeze-dried and mixed. Portions were taken for analysis. Continuous daily collections of urine were made by the subjects during the last $12 \mathrm{~d}$ of each 24-d-period. Urine was collected into acid-washed plastic bottles containing $20 \mathrm{ml} \mathrm{5M-hydrochloric} \mathrm{acid.} \mathrm{The} \mathrm{volumes} \mathrm{were} \mathrm{measured} \mathrm{and} \mathrm{the} \mathrm{urine} \mathrm{pooled} \mathrm{in} \mathrm{3-d-lots.}$ Portions were taken for analysis.

\section{Chemical analyses}

$\mathrm{Zn}, \mathrm{Ca}$ and $\mathrm{Mg}$ were measured in diets, faeces and urine, and $\mathrm{Fe}$ in diets and faeces. The freeze-dried samples were dry-ashed at $450^{\circ}$ and $\mathrm{Zn}, \mathrm{Ca}, \mathrm{Mg}$ and $\mathrm{Fe}$ were measured in an acid-extract of the ashed samples using a Perkin Elmer 360 atomic absorption spectrophotometer. Urine was diluted with deionized water, lanthanum oxide was added for the $\mathrm{Ca}$ and $\mathrm{Mg}$ analyses and the content of $\mathrm{Zn}, \mathrm{Ca}$ and $\mathrm{Mg}$ was determined as described previously.

Non-starch polysaccharides (NSP) are the major components of 'dietary fibre'. The NSP contents of the breads were measured by the method of Englyst et al. (1982). The polysaccharides were divided into cellulose and non-cellulosic material. The non-cellulosic polysaccharide was further separated into soluble and insoluble fractions after extraction at pH 7. Phytic acid was measured by Davies \& Reid's (1979) modification of the procedure of Holt (1955).

The results presented in the present paper were from values obtained during the last $12 \mathrm{~d}$ of each dietary period. Dermal losses are not included in calculations of the balances. Results are given as mean values and $1 \mathrm{SD}$. Wilcoxon matched-pairs signed-rank test has been used in the statistical analysis.

\section{RESULTS}

Phytate and NSP intakes

After baking, the phytate contents ( $\mathrm{mmol} / 200 \mathrm{~g}$ bread) of the three breads were: white $2 \cdot 3$, brown $2 \cdot 1$, wholemeal $2 \cdot 2$. 


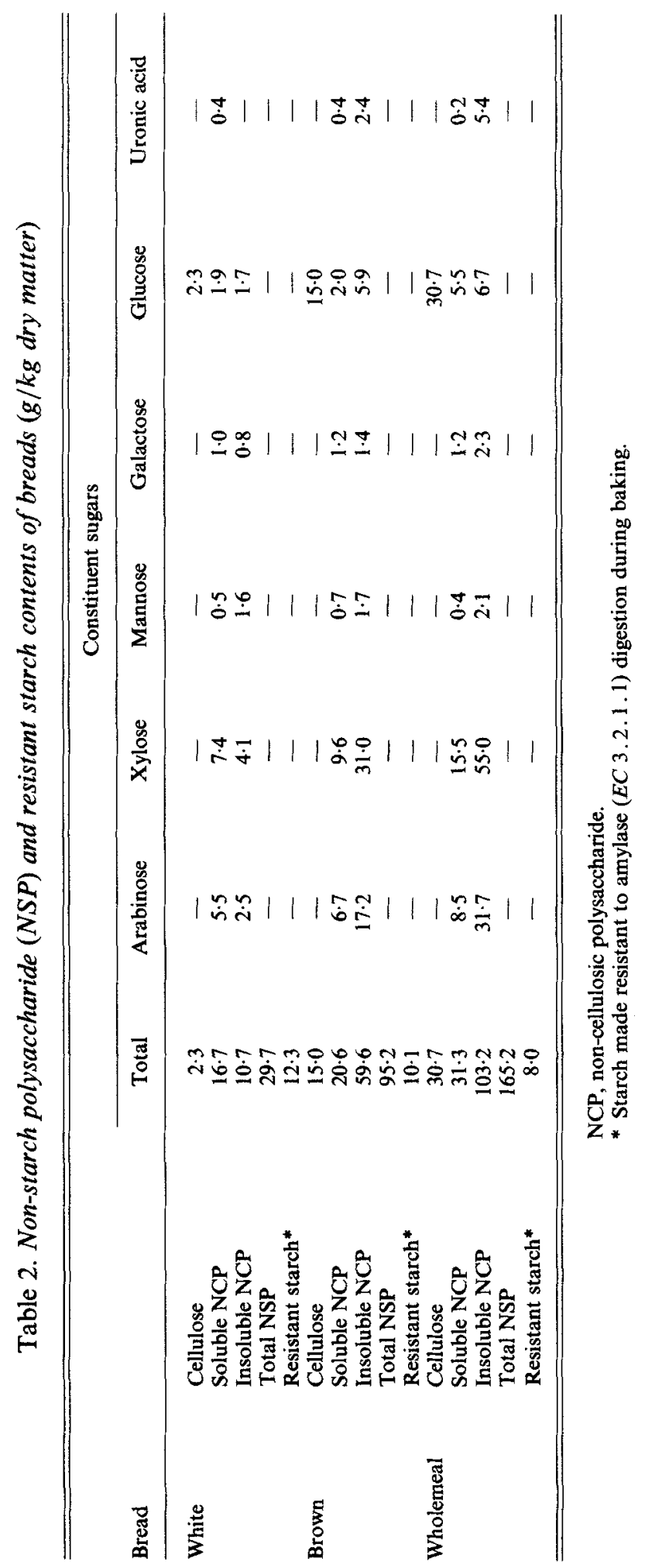


Phytate, fibre and mineral absorption

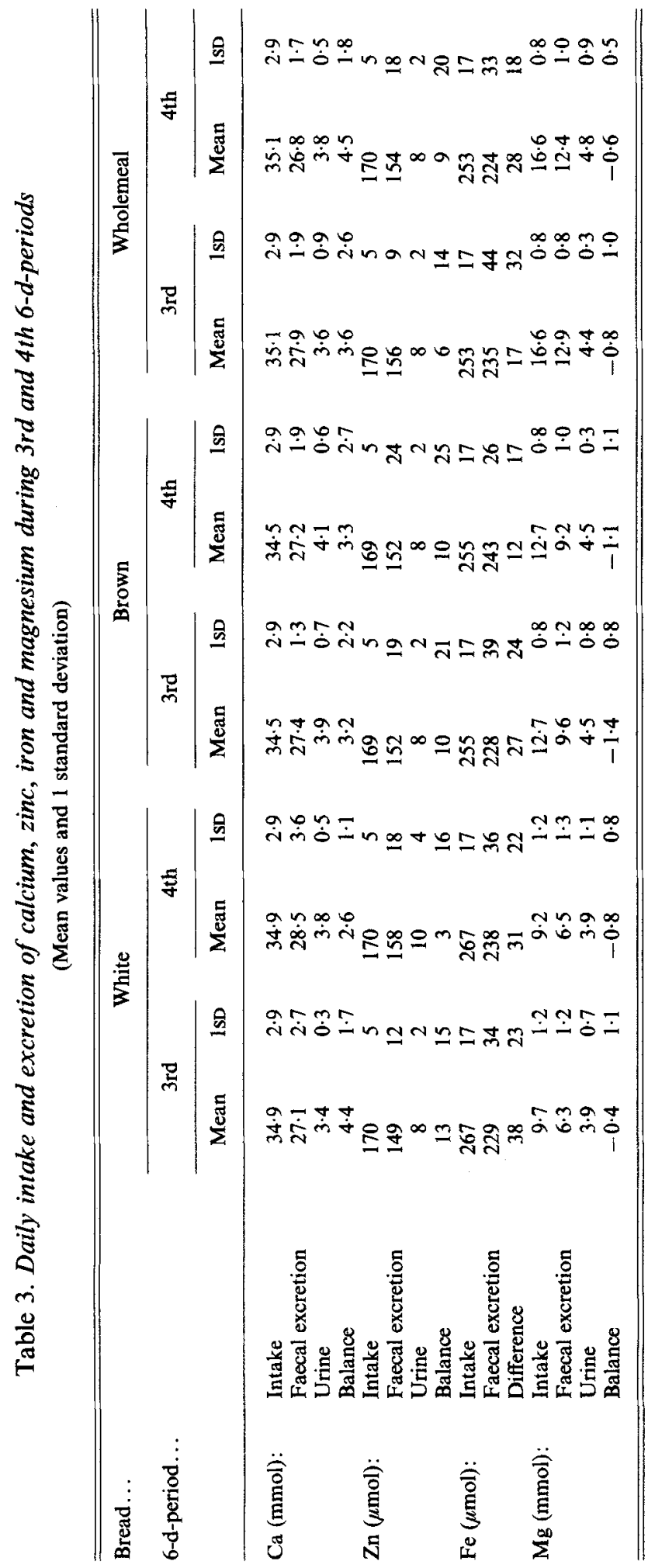


The NSP contents of the breads are given in Table 2 . The dry weights $(\mathrm{g} / \mathrm{kg})$ of the three breads (measured on six separate samples of each) were: white 556, brown 570 , wholemeal 565 . In $200 \mathrm{~g}$ of the fresh bread, therefore, the amounts of NSP (g) the subjects received were: white $3 \cdot 30$, brown $10 \cdot 9$, wholemeal $18 \cdot 7$. The mean (with SE) total dietary fibre intakes $(\mathrm{g} / \mathrm{d})$ (calculated from food tables) for the whole group were: white bread diet $16 \cdot 1(0 \cdot 97)$, brown $23.7(0.97)$, wholemeal $31.5(0.97)$.

\section{Marker recovery}

During the study the subjects received a total of 12750 markers. Over-all recovery was 99.4 (SE 0.4$) \%$.

\section{Stool weight and transit time}

Mean (with SE) stool output on the white bread diet was 137 (38) $\mathrm{g} / \mathrm{d}$ increasing to 175 $(50) \mathrm{g} / \mathrm{d}$ with brown bread $(t 3.35, P<0.025)$ and increasing further with wholemeal bread to $236(51) \mathrm{g} / \mathrm{d}$ ( $t$ (brown $v$. wholemeal) $4.04, P<0.01$ ). Faecal solids $(\mathrm{g} / \mathrm{d}$ ) increased similarly; white bread $28.7(5 \cdot 1)$, brown bread $37.0(5 \cdot 9)$, wholemeal bread $47.5(6 \cdot 4)$. Changes in MTT were less consistent although over-all there was a trend towards shorter MTT (h) with the higher fibre intakes: white bread 46.4 (16.7), brown 41.3(13.4), wholemeal $39.4(11.8)$. None of the changes in MTT was statistically significant.

\section{Mineral balances}

As may be seen from Table 3 there was no significant effect on $\mathrm{Ca}, \mathrm{Zn}, \mathrm{Fe}$ or $\mathrm{Mg}$ balance due to the different breads. All the subjects were maintained in Ca balance $(3.6 \mathrm{mmol} / \mathrm{d})$. Mean (with SE) daily faecal Ca excretion (mmol) was unchanged at: white bread $27 \cdot 8(3 \cdot 1)$, brown $27 \cdot 3(1.6)$, wholemeal $27 \cdot 3(1.8)$. The group as a whole were in positive $\mathrm{Zn}$ balance $(8 \mu \mathrm{mol} / \mathrm{d})$ throughout the study over-all, daily faecal excretion ( $\mu \mathrm{mol})$ being: white bread 154 (15), brown 152 (21), wholemeal 155 (13). Two subjects were in positive $\mathrm{Zn}$ balance ( $\mu \mathrm{mol} / \mathrm{d}$ ) throughout, one in negative balance (white -12 , brown -19 , wholemeal -3 ) whilst the other three minerals showed no consistent pattern. Fe balance was also positive and was unchanged by the different breads.

$\mathrm{Mg}$ intake increased as the amount of bran in the bread increased so faecal and urine $\mathrm{Mg}$ excretion also increased. Balance was negative throughout in all subjects by approximately $0.8 \mathrm{mmol} / \mathrm{d}$.

Serum $\mathrm{Ca}, \mathrm{Zn}$ and $\mathrm{Mg}$ levels were within the normal range for all subjects and were unchanged by the different diets. Serum Fe was low in three subjects and fell throughout the study probably due to the frequent blood sampling rather than to any dietary effects. The values (per 1) for $\mathrm{Ca}, \mathrm{Zn}, \mathrm{Mg}$ and $\mathrm{Fe}$ respectively expressed as the mean (range) for the six volunteers were: $2 \cdot 3(2 \cdot 0-2 \cdot 5) \mathrm{mmol}, 12 \cdot 0(10.9-16 \cdot 6) \mu \mathrm{mol}, 0.94(0 \cdot 84-1 \cdot 0) \mathrm{mmol}$, $15(5 \cdot 0-34) \mu \mathrm{mol}$.

\section{DISCUSSION}

The aim of the present study was to measure the effect which wheat bran might have on mineral balance independent of the known effect of phytate. Since both phytate, NSP and other cell-wall materials are present together in wheat bran there are practical difficulties in separating their effects in human feeding studies. The results of our study indicate that if the effect of phytate is excluded other substances present in wheat bran produce no detectable change in mineral balance. Our values for Fe retention, however, show a tendency to decrease with increasing amounts of bran in the diet. This suggests that there is some substance in bran, beside phytic acid, which may have a slight negative effect on Fe absorption. 
Although Mellanby (1949) had identified phytate as a substance present in cereals which inhibited mineral absorption, it was McCance \& Widdowson $(1942 a, b)$ who first showed the effect which phytate present in wheat bran has on $\mathrm{Ca}$ absorption in man. To determine the action of phytate they gave their subjects white bread and brown bread made without the use of yeast to minimize breakdown of phytate and, in addition, dephytenized brown bread. Bread provided $40-50 \%$ of energy and $\mathrm{Ca}$ absorption was similar from the white and dephytenized brown but less from the brown bread with its phytate still present. In a further study sodium phytate was added to white bread and $\mathrm{Ca}$ absorption was shown to be reduced by it. These studies identified phytic acid as having an inhibitory effect on $\mathrm{Ca}$ absorption but did not exclude the possibility that other cell wall constituents, especially the NSP, might be having an effect since the dephytenization step in their studies involved heating the bran in water at $\mathrm{pH} 4.5$ for $6 \mathrm{~h}$, a process which would solubilize some of the NSP and also break down some of the non-cellulosic polysaccharides. Of the bran $30 \%$ was lost during this dephytenization process. These observations have also been supported by studies in rats. The availability of Fe (Morris \& Ellis 1980) and of Zn (Davies et al. 1977) decreased when phytic acid was added or increased when the bran was dephytenized in these animal studies.

The preparation of dephytenized cereals is difficult. In order to overcome the problem of damaging other cell wall substances during dephytenization we tried to destroy phytate in bran by prolonging the rising stage of bread to $24 \mathrm{~h}$ to allow a longer time for naturally-present phytase $(E C 3.1,3.26)$ to act. Neither this nor adding additional phytase to the dough reduced phytate levels to below approximately $50 \%$ of that present in wholemeal flour. As an alternative, therefore, it was decided to add phytate to white and brown breads to bring the levels up to that present in wholemeal bread after baking. After some experimentation it was found to be possible to do this. When these breads were fed at 16.5 (SE 1.4)\% of energy intake no significant effect on mineral balance was seen. The same breads as have been used in the present study have also been fed to rats in an experiment reported by Fairweather-Tait (1982). No effect on Fe absorption was observed in the rat study.

We have previously shown (Cummings et al. 1979), using the same balance techniques, that subjects transferring from white to wholemeal bread and adding raw bran + All-Bran ${ }^{\circledR}$ (Kellogg Co.) to their diet causes them to go into negative $\mathrm{Ca}$ balance over a 3-week-period. The contrast with the results from the present study confirm the potential of wholemeal products to inhibit $\mathrm{Ca}$ absorption but identify phytate rather than other cell wall components as the cause of this inhibition.

The previous studies of Reinhold et al. $(1975,1976)$, which suggest that fibre may be important in preventing mineral absorption, are largely based on in vitro work. In fact earlier work by Reinhold's group (Reinhold et al. $1973 a, b$ ) indicated that phytic acid was a major cause of mineral malabsorption. Simpson et al. (1981) have suggested that $\mathrm{Fe}$ absorption is inhibited more by fibre than by phytate. In their study, monoferric phytate added to the diet was no less well absorbed than non-haem dietary Fe. The phytic acid content of the diet was, however, much less than if bran had been added.

The importance of identifying phytate as the major cause of mineral malabsorption in products containing bran lies in the widespread use of bran in clinical practice. To avoid the dangers of mineral imbalance, raw bran should be avoided.

A better source of fibre is food such as wholemeal bread where the action of phytase in yeast will have reduced the mineral-binding capacity of the phytate very considerably during fermentation. Alternatively, dephytenized bran products which are now becoming available may be useful. 
The authors thank the six volunteers who took part in this study without whose perseverance it would not have been possible. They also thank Ms Sue Fisher and Ms Betty Lucas for preparing all food, Ms Monica Johnsson for technical assistance, Dr Göran Lindstedt for performing blood analyses and Dr Russell Eggett of Dalgety-Spillers for considerable help in making breads for the study.

This work was supported by grants from the Swedish National Board for Technical Developments, Marabou Company and MEDA, Sweden.

\section{REFERENCES}

Andersson, H., Bosaeus, I., Falkheden, T. \& Melkersson, M. (1979). Scandinavian Journal of Gastroenterology 14, $821-826$.

Bingham, S., Cummings, J. H. \& McNeil, I. (1981). British Journal of Nutrition 45, 23-35.

Branch, W. J. \& Cummings, J. H. (1978). Gut 19, 371-376.

Cummings, J. H., Hill, M. J., Jivraj, T., Houston, H., Branch, W. J. \& Jenkins, D. J. A. (1979). American Journal of Clinical Nutrition 32, 2086-2093.

Cummings, J. H., Jenkins, D. J. A. \& Wiggins, H. S. (1976). Gut 17, 210-218.

Davies, N. T., Hristic, V. \& Flett, A. A. (1977). Nutrition Reports International 15, 207-214.

Davies, N. T. \& Reid, H. (1979). British Journal of Nutrition 41, $579-589$.

Drews, L. M., Kies, C. \& Fox, H. M. (1979). American Journal of Clinical Nutrition 32, 1893-1897.

Englyst, H. E., Wiggins, H. S. \& Cummings, J. H. (1982). Analyst, London 107, 307-318.

Fairweather-Tait, S. J. (1982). British Journal of Nutrition 47, 243-249.

Holt, P. (1955). Journal of the Science of Food and Agriculture 6, 136-142.

Kelsay, J. L., Jacob, R. A. \& Prather, E. S. (1979). American Journal of Clinical Nutrition 32, $2307-2311$.

Kies, C., Fox, H. M. \& Beshgetoor, D. (1979). Cereal Chemistry 56, 133-136.

McCance, R. A. \& Widdowson, E. M. (1942a). Journal of Physiology 101, 44-85.

McCance, R. A. \& Widdowson, E. M. (1942b). Journal of Physiology 101, 304-313.

Mellanby, E. (1949). Journal of Physiology 109, 488-533.

Morris, E. R. \& Ellis, R. (1980). Journal of Nutrition 110, 2000-2010.

Paul, A. A. \& Southgate, D. A. T. (1978). McCance \& Widdowson's The Composition of Foods, 4th ed. London: H.M. Stationery Office.

Persson, I., Raby, K., Fönss-Bech, P. \& Jensen, E. (1976). Journal of American Geriatrics Society 24, 334-335.

Reinhold, J. G., Faradji, B., Abadi, P. \& Ismail-Beigi, F. (1976). In Trace Elements in Human Health and Disease, vol 1, pp. 163-180 [A. S. Prasad and D. Oberleas, editors]. London: Academic Press.

Reinhold, J. G., Hedayati, H., Lahimgarzadeh, A. \& Nasr, K. (1973b). Ecology of Foods and Nutrition 2, $157-162$.

Reinhold, J. G., Ismail-Beigi, F. \& Faradji, B. (1975). Nutrition Reports International 12(2), 75-85.

Reinhold, J. G., Lahimgarzadeh, A., Nasr, K. \& Hedayati, H. (1973a). Lancet i, 283-288.

Royal College of Physicians (1980). Medical Aspects of Dietary Fibre. London: Pitman Medical.

Sandberg, A.-S., Hasselblad, C. \& Hasselblad, K. (1982). British Journal of Nutrition 48, 185-191.

Sandstead, H. H., Muños, J. M., Jacob, R. A., Klevay, L. M., Reck, S. J., Logan, G. M. Jr, Dintzis, F. R., Inglett, G. E. \& Shuey, W. C. (1978). American Journal of Clinical Nutrition 31, S180-S184.

Sandström, B., Arvidsson, B., Cederblad, Å. \& Björn-Rasmussen, E. (1980). American Journal of Clinical Nutrition 33, 739-745.

Simpson, K. M., Morris, E. R. \& Cook, J. D. (1981). American Journal of Clinical Nutrition 34, $1469-1478$. 